\title{
Doses of calcium sulphate increase the peroxidase activity and the rooting of eucalyptus clones
}

\author{
Doses de sulfato de cálcio incrementam a atividade de peroxidase e o \\ enraizamento de clones de eucalipto
}

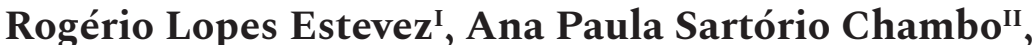 José Renato Stangarlin ${ }^{\text {III }}$, Odair José Kuhn ${ }^{\text {IV }}$}

\begin{abstract}
Due to the demand of the forest-based sector and the difficulty for providing seedlings of Eucalyptus spp. produced by cutting rooting, the objective of this study was to evaluate if doses of a calcium sulphatebased fertilizer increase the peroxidase activity and the rooting of two eucalyptus clones. The study was conducted using cuttings of the eucalyptus clones IPB22 and IBP26 (Eucalyptus grandis x Eucalyptus urophylla), in which bi-weekly applications of the fertilizer were carried out in the aerial part of the plants for 120 days at dosages of $0,40,80,160$ and $320 \mathrm{~g} \mathrm{~L}^{-1}$ in indoor experimental nursery. The analyzed variables were shoot height and diameter, rooting percentage and peroxidase activity. We observed that the use of doses of calcium sulphate based fertilizer, mainly 160 and $320 \mathrm{~g} \mathrm{~L}^{-1}$, increased the height, diameter, rooting and peroxidase of the mini-cuttings for both clones. Thus, this fertilizer induces the peroxidase activity, contributing to a better development of eucalyptus mini-cuttings.
\end{abstract}

Keywords: Eucalyptus grandis; Eucalyptus urophylla; Cutting; Vegetative propagation; Forest nutrition; Forest fertilization

\section{Resumo}

Diante da demanda do setor florestal em fornecer mudas de Eucalyptus sp. e devido à dificuldade de enraizamento a partir de estacas, o presente trabalho objetivou avaliar se doses de um fertilizante mineral à base de sulfato de cálcio incrementa a atividade de peroxidase e o desenvolvimento radicular de dois clones de eucalipto. O estudo foi conduzido utilizando os clones de eucalipto IPB22 e IBP26 (Eucalyptus grandis x Eucalyptus urophylla), nos quais foram realizadas aplicações quinzenais do fertilizante, por 120 dias na parte aérea das plantas, nas dosagens de $0,40,80,160$ e $320 \mathrm{~g} \mathrm{~L}^{-1} \mathrm{em}$ casa de vegetação. As variáveis analisadas foram altura da parte aérea, diâmetro do colo, porcentagem de enraizamento e atividade da enzima peroxidase. A aplicação do fertilizante à base de sulfato de cálcio, principalmente em 160 e $320 \mathrm{~g}$ $\mathrm{L}^{-1}$, resultou em maior altura, diâmetro de colo, enraizamento das miniestacas e atividade de peroxidase para os dois clones estudados. Dessa forma, conclui-se que esse fertilizante induz a atividade de peroxidase, contribuindo para melhor desenvolvimento de miniestacas de clones de eucalipto.

Palavras-chave: Eucalyptusgrandis; Eucalyptus urophylla; Produção de mudas; Propagação vegetativa; Nutrição florestal; Fertilização florestal

Engenheiro Agrônomo, Dr., Pesquisador P\&D na Empresa BMA Agro, Rua Ildefonso Maioli, s/n, CEP 86900-000, Jandaia do Sul (PR), Brasil. estevezpr@hotmail.com (ORCID: 0000-0001-5009-4402)

Zootecnista, Dra., pesquisadora autônoma, Av. João Paulino Vieira Filho, 35, CEP 87020-015, Maringá (PR), Brasil. anachambo@gmail.com (ORCID: 0000-0002-2953-8280)

III Engenheiro Agrônomo, Dr., Professor Associado C da Universidade Estadual do Oeste do Paraná, Centro de Ciências Agrárias, Rua Pernambuco, 1777, CEP 85960-000, Marechal Cândido Rondon (PR), Brasil. jose.stangarlin@unioeste.br (ORCID: 0000-0001-8601-9439)

IV Engenheiro Agrônomo, Dr., Professor Associado A, Centro de Ciências Agrárias, Universidade Estadual do Oeste do Paraná, Rua Pernambuco, 1777, CEP 85960-000, Marechal Cândido Rondon (PR), Brasil (ORCID: 0000-0002-6803-4579) 


\section{Introduction}

The area of silviculture for industrial purposes in Brazil has been growing approximately $2 \%$ in the last three years. Eucalyptus, which is one of the most representative species in the sector, occupies 5.56 million hectares, with an average yield of $39 \mathrm{~m}^{3} \mathrm{ha}^{-1}$ year ${ }^{-1}$. Considering the projection of 9.5 billion inhabitants in 2050 made by the United Nations (FAO) in 2015, to supply the demand of this contingent in 35 years, it would be necessary an additional planting of about 210 million hectares of eucalyptus worldwide, within current levels of productivity (INDÚSTRIA BRASILEIRA DE ÁRVORES, 2016).

In silviculture eucalyptus is one of the most cultivated species because it has favorable characteristics to the production as a great diversity, since the genus Eucalyptus has approximately 700 species, fast growth and high forest productivity (ALFENAS et al., 2009). However, the growth of this culture presents some challenges, such as the difficulty of propagation by using minicuttings. Some species of the genus Eucalyptus are known to be recalcitrant to rooting of cutting stakes (ASSIS; MAFIA, 2007), and the plantations have been restricted to temperate regions due to their edaphoclimatic requirements (FREITAS JUNIOR; MARSON; SOLERA, 2012).

Given the context, to adapt to this new world scenario and overcome these challenges, companies in the sector are investing in biotechnology, associated with genetic improvement. For the tree sector, the production of good quality seedlings, in a shorter time (FERNANDES et al., 2018), is of extreme importance, since it has a direct impact on the success of the implantation and establishment of the stands (MARTINS; SILVA; STRECK, 2007).

However, one of the main problems is the difficulty of seedling production by the rooting of cuttings, making it difficult to take advantage of the benefits of cloning (BORGES et al., 2011). The formation of roots in cuttings is a complex anatomical and physiological process that can be influenced by several factors, such as injuries, hormonal balance, genetic constitution, presence of inhibitors and nutritional and water conditions of the propagating plant (ALFENAS et al., 2009).

However, the application of root-promoting substances may generate better results in the vegetative propagation of plants. Some substances stand out as rooting promotor, such as natural and synthetic auxins (HARTMANN et al., 2002), calcium, which can increase the activity of peroxidase, the key enzyme involved in lignin synthesis pathway (HAISSING, 1986), and inducers of resistance in plants against pathogens, such as acibenzolar-S-methyl (ASM) (BOAVA et al., 2010). According to Amarante et al. (2001), the increase in the specific activity of the peroxidase before the initiation and growth of the root primordia in micropropagated plants can serve as a marker of the rooting performance, which was also verified in other studies (GASPAR et al., 1992; ANSARI; PALANISAMY; KUMAR, 1995; MATO; RÚA; FERRO, 1998). This enzyme is directly linked to the lignification of tissues and, consequently, it is important to increase the resistance in plants. Thus, any compound or product able to improve the root performance could increase the amount of the seedling production.

In this context, the objective of this work was to evaluate if doses of a calcium sulphatebased mineral product increases the peroxidase activity in Eucalyptus spp. during rooting process.

\section{Material and methods}

The experiment was conducted in a commercial clonal eucalyptus garden, located in São Paulo, Brazil. The climate of this region is Cwb (rainy summers and cold and dry winters), according to the classification of Köppen, with latitude $22^{\circ} 13^{\prime} \mathrm{S}$, longitude $46^{\circ} 33^{\prime} \mathrm{W}$ and average altitude of $640 \mathrm{~m}$. The average annual temperature is $21.7^{\circ} \mathrm{C}$, with maximum average of $29.7^{\circ} \mathrm{C}$ and average minimum of $10.6^{\circ} \mathrm{C}$. During the experimental period, the average temperature was $21.4{ }^{\circ} \mathrm{C}$, with an average maximum of $22.8^{\circ} \mathrm{C}$ and a mean of the minimum of $19.6^{\circ} \mathrm{C}$. 
The clones IPB 22 and IBP26 from the hybrid Eucalyptus grandis x Eucalyptus urophylla were used. Plants were obtained by the technique of mini-cutting. The clonal minigarden was installed in the Indoor Experimental Nursery of the commercial clonal eucalyptus garden. The clonal minigarden was constituted of mini-stumps, obtained by the rooting of mini-cuttings originating from sprouts of plants propagated by the method of the micro-stem. The management system of the clonal mini-garden adopted was the commercial one used by the company, where the mini-stumps remained in concrete channels. Irrigation and mineral nutrition were carried out through the automated flood fertigation system, so that only the root system remained in contact with the nutrient solution composed of calcium nitrate $\left(0.04 \mathrm{~g} \mathrm{~L}^{-1}\right)$ and ammonium sulfate $\left(0.216 \mathrm{~g} \mathrm{~L}^{-1}\right)$.

The mini-cuttings were collected weekly in the clonal mini-garden and conditioned in transparent PVC boxes in phenolic foam and kept closed to maintain the turgescence conditions of the vegetative material. The rooting process of mini-cuttings was carried out in a greenhouse $\left(80 \%\right.$ air relative humidity and $27{ }^{\circ} \mathrm{C}$ temperature) with a 25 -day stay. Subsequently, the minicuttings were transferred to the shade house (ten days for acclimatization) and finally to full sun until reaching 50 days of age. Bi-weekly applications of Fert Protetor ${ }^{\circledR}$ (calcium sulphate-based mineral fertilizer) were carried out in the aerial part of the plants, at the dosages of $0,40,80,160$ and $320 \mathrm{~g} \mathrm{~L}^{-1}$ for 120 days.

The experimental design was completely randomized, in factorial arrangement $5 \times 2$, with the first factor being the calcium sulphate-based product dosages and the second factor the clones (IPB22 and IPB26), with four replications.

The total experimental area consisted of one trial of 20 meters, each plot being onemeter long. For the evaluations, all viable sprouts were removed from the central area of each experimental unit, scraping $15 \mathrm{~cm}$ from each side. Clonal eucalyptus seedlings were evaluated every 15 days from the withdrawal of the mother plant.

The analyzed variables were shoot height, stem diameter, rooting percentage and peroxidase activity. For the evaluation of the aerial part and stem diameter, 16 seedlings were sampled at 50 days in the central area of each plot. For the rooting percentage, all the plants of the useful area were quantified at 25 and 50 days.

The height was measured in centimeters $(\mathrm{cm})$, from the base of the shoots to the apical meristem using a ruler. The diameter of the collar was measured at the base of the cutting, on the surface of the substrate, with the aid of a pachymeter. The determination of the rooting percentage was obtained through the relation between sprouts removed and viable seedlings.

For the analysis of peroxidase, the samples were collected at 0, 24, 72 and 96 hours after the calcium sulphate-based fertilizer treatment, being stored in freezer at $-80{ }^{\circ} \mathrm{C}$ until the determination of the enzymatic activity. Samples of $0.5 \mathrm{~g}$ of leaves from each treatment were macerated with liquid nitrogen in a mortar and then homogenized in $4 \mathrm{~mL}$ of $0.1 \mathrm{M}$ sodium acetate buffer $\mathrm{pH} 5.0$, containing $2.56 \mathrm{~g}$ of polyvinylpyrrolidone and fluoride phenylmethylsulfonyl 5 $\mathrm{mM}$. The extracts were centrifuged at $20,000 \mathrm{~g}$ for $25 \mathrm{~min}$ at $4{ }^{\circ} \mathrm{C}$ and the supernatant, considered the protein fraction, was transferred to microtubes and stored at $-20^{\circ} \mathrm{C}$. Peroxidase activity was determined at $30{ }^{\circ} \mathrm{C}$ by a direct spectrophotometric method by measuring the conversion of guaiacol to tetraguaiacol at $470 \mathrm{~nm}$ (LUSSO; PASCHOLATI, 1999).

Data were submitted to analysis of variance and quantitative variables analyzed by regression, using the statistical program Sisvar 5.6 (FERREIRA, 2014).

\section{Results and discussion}

The height of Eucalyptus grandis x Eucalyptus urophylla minicuttings did not show significant differences $(p>0.05)$ for interaction between the clones and the dosages of calcium sulphate-based fertilizer, obtaining a mean height of $15.46 \mathrm{~cm}$, with coefficient of variation of 
$1.82 \%$. However, regardless of the clones studied, the mini-cutting height varied significantly according to the doses of treatment. The quadratic regression model provided a better fit to express the effect of treatment doses, at the time of mini-cutting of the clones (Figure 1). In this way, it can be observed that according to the applied doses there was a significant increase in the mini-cutting height, resulting in an increase of up to $5 \%$. The calculated dose of fertilizer that provides the greater increase is $288 \mathrm{~g} \mathrm{~L}^{-1}$.

Figure 1 - Height of mini-cuttings $(\mathrm{cm})$ in full sun at 50 days of age, as a function of calcium sulphate-based fertilizer doses, of two clones (IPB22 and IPB26) of Eucalyptus grandis $x$ Eucalyptus urophylla. *Significanttotest t at $\mathbf{5 \%}$ probability

Figura 1 - Altura de miniestacas ( $\mathrm{cm}$ ) a pleno sol aos 50 dias de idade, em função de doses de fertilizante à base de sulfato de cálcio, de dois clones (IPB22 e IPB26) de Eucalyptus grandis x Eucalyptus urophylla. ${ }^{*}$ Significativo pelo teste t a $5 \%$ de probabilidade

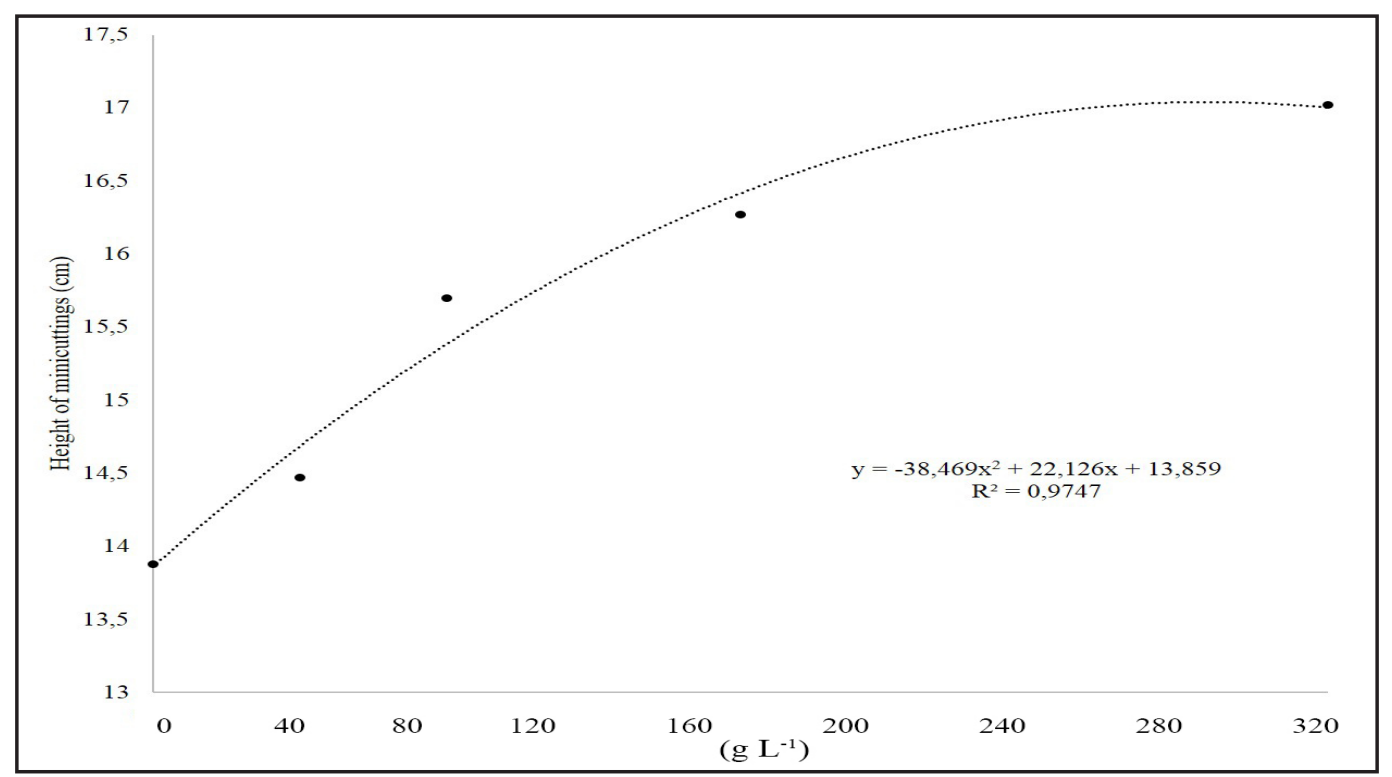

Source: Authors (2017)

The height of plants is a factor used to estimate the seedling quality standard in forest nurseries. As quality criteria, companies adopt average height ranging from 15 to $30 \mathrm{~cm}$ in the main Eucalyptus species planted in the country (XAVIER; WENDLING; SILVA, 2009). Considering this standard, the mean values for the minicuttings submitted to calcium sulphatebased fertilizer dosages, obtained in the present study, are within the quality standards, except for the $40 \mathrm{~g} \mathrm{~L}^{-1}$ dosage that remained at the threshold $(14.47 \mathrm{~cm})$. The treatment without addition of this fertilizer obtained mean values $(13.88 \mathrm{~cm})$ lower than the one desired by the company.

Some authors also support the adoption of a specific height as a quality standard. For example, Souza et al. (2013), studying patterns of mini-cuttings and seasonality in the production of clonal seedlings of E. grandis $\mathrm{x}$ E. urophylla found that seedlings with more than $10 \mathrm{~cm}$ in height provide a better rooting rate, as well as better seedling development.

According to Souza et al. (2006), the height and the diameter of the stem are fundamental for the evaluation of the potential of survival and growth in the post-planting of seedlings of forest species, since, within a same species, larger diameter plants present greater survival because they have capacity for formation and growth of new roots.

The diameter of the mini-cuttings stem did not differ significantly between the IPB22 and IPB26 clones evaluated, obtaining average values of $1.19,1.24,1.28,1.29$ and $1.32 \mathrm{~mm}$, 
respectively for the dosages of $0,40,80,160$ and $320 \mathrm{~g} \mathrm{~L}^{-1}$ of fertilizer. However, regardless of the clones evaluated, the diameter of the stem of the mini-cuttings obtained an increase of approximately $10 \%(\mathrm{p}<0.05)$ in the best dose response that was with the application of $270 \mathrm{~g} \mathrm{~L}^{-1}$ of calcium sulphate-based fertilizer. These facts can best be exemplified by observing the quadratic regression $\left(R^{2}=0.92\right)($ Figure 2$)$.

Figure 2 - Stem diameter of the mini-cuttings $(\mathrm{cm})$ in full sun at 50 days of age, as a function of doses of calcium sulphate-based fertilizer, of two clones (IPB22 and IPB26) of Eucalyptus grandisx Eucalyptus urophylla. *Significanttotest t at 5\% probability

Figura 2 - Diâmetro do colo de miniestacas $(\mathrm{cm})$ a pleno sol aos 50 dias de idade, em função de doses de fertilizante à base de sulfato de cálcio, de dois clones (IPB22 e IPB26) de Eucalyptus grandis x Eucalyptus urophylla. ${ }^{*}$ Significativo pelo teste t a $5 \%$ de probabilidade

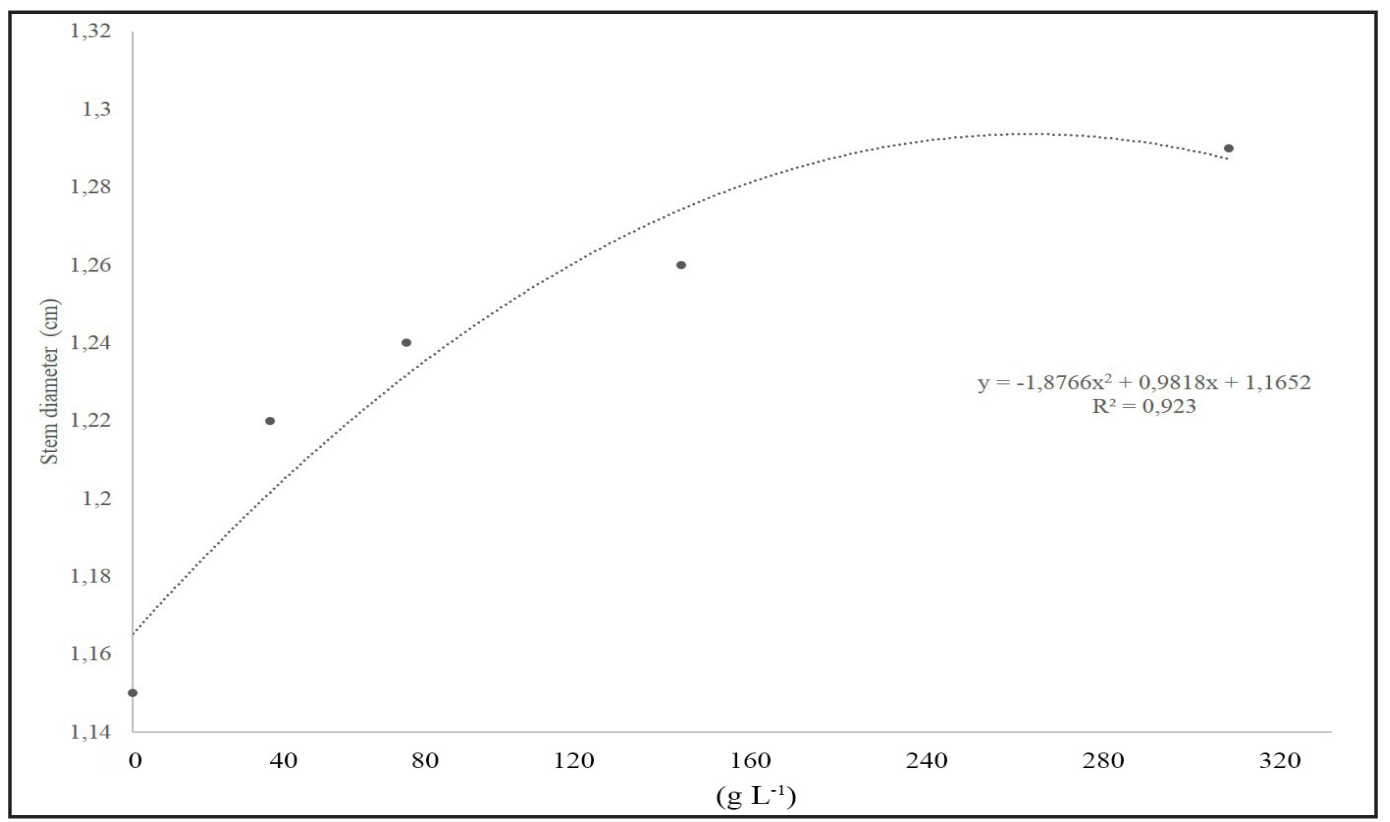

Source: Authors (2017)

Both the height and the diameter of the stem are easy to measure, and their evaluations are not destructive, so they are frequently used to estimate the quality of seedlings in forest nurseries. For the stem diameter, values higher than $2 \mathrm{~mm}$ are indicative of higher quality and survival rate for the main Eucalyptus species planted in Brazil (XAVIER; WENDLING; SILVA, 2009).

Similar values to the present study for height and stem diameter of mini-cuttings were also verified by Correira et al. (2015), when studying leaf reduction in mini-cuttings and micro-shoots of hybrids of Eucalyptus globulus, whose average values were $15.3 \mathrm{~cm}$ and $2.0 \mathrm{~mm}$, respectively for height and stem diameter.

The percentage of rooting of the mini-cuttings of the IPB22 and IPB26 clones of Eucalyptus was evaluated in two moments, at the exit of the shade house at 25 days of age, characterized as season 1, and at full sun at 50 days of age, season 2 . The evaluation of mini-cuttings rooting for both seasons had the same behavior, with no interaction $(\mathrm{p}<0.05)$ between the evaluated clones (IPB22 and IPB26) at the studied doses. However, there was an increase of rooting according to the dosages of calcium sulphate-based fertilizer, independently of the clones.

The use of doses of that fertilizer promoted an increase in the rooting of mini-cuttings. Treatment at the concentration of $160 \mathrm{~g} \mathrm{~L}^{-1}$ was more effective $(\mathrm{p}<0.05)$, increasing the rooting rate 
from $58 \%$ to $81 \%$ and from $56 \%$ to $83 \%$, corresponding to a $30 \%$ and $33 \%$ increase, for periods 1 (Figure 3a) and 2 (Figure 3b), respectively. These statements are best exemplified in the quadratic regression graphs discussed in Figure $3 \mathrm{a}$ and Figure $3 \mathrm{~b}$.

The competitiveness of the forest-based industry has one of the main problems the difficulty of vegetative propagation of seedlings, due to difficulties in the rooting process of cuttings in some species and clones, particularly Eucalyptus (ASSIS; MAFIA, 2007; ALFENAS et al., 2009; XAVIER; WENDLING; SILVA, 2009). According to Alfenas et al. (2009), less than 2\% of the Eucalyptus globulus elite trees selected in breeding programs show mini-cuttings roots equal to or greater than $60 \%$. This value corroborates the obtained in the present study (Figure 3a and $3 \mathrm{~b})$, since the plants not treated with doses of fertilizer did not reach a rooting rate higher than $60 \%$ in any of the studied periods.

Figure 3 - Rooting rate of two clones (IPB22 and IPB26) of Eucalyptus grandis x Eucalyptus urophylla as a function of doses of calcium sulphate-based fertilizer, in two seasons. Season 1 (a), at 25 days at the exit of shade house; season 2 (b) at 50 days in full sun. ${ }^{*}$ Significanttotest $t$ at $\mathbf{5 \%}$ probability

Figura 3 - Taxa de enraizamento de dois clones (IPB22 e IPB26) de Eucalyptus grandis x Eucalyptus urophylla em função de doses de fertilizante à base de sulfato de cálcio, em duas épocas. Época 1 (a), aos 25 dias na saída de casa de sombra; época 2 (b) aos 50 dias em pleno sol.

${ }^{*}$ Significativopelo teste $\mathrm{t}$ a $5 \%$ de probabilidade

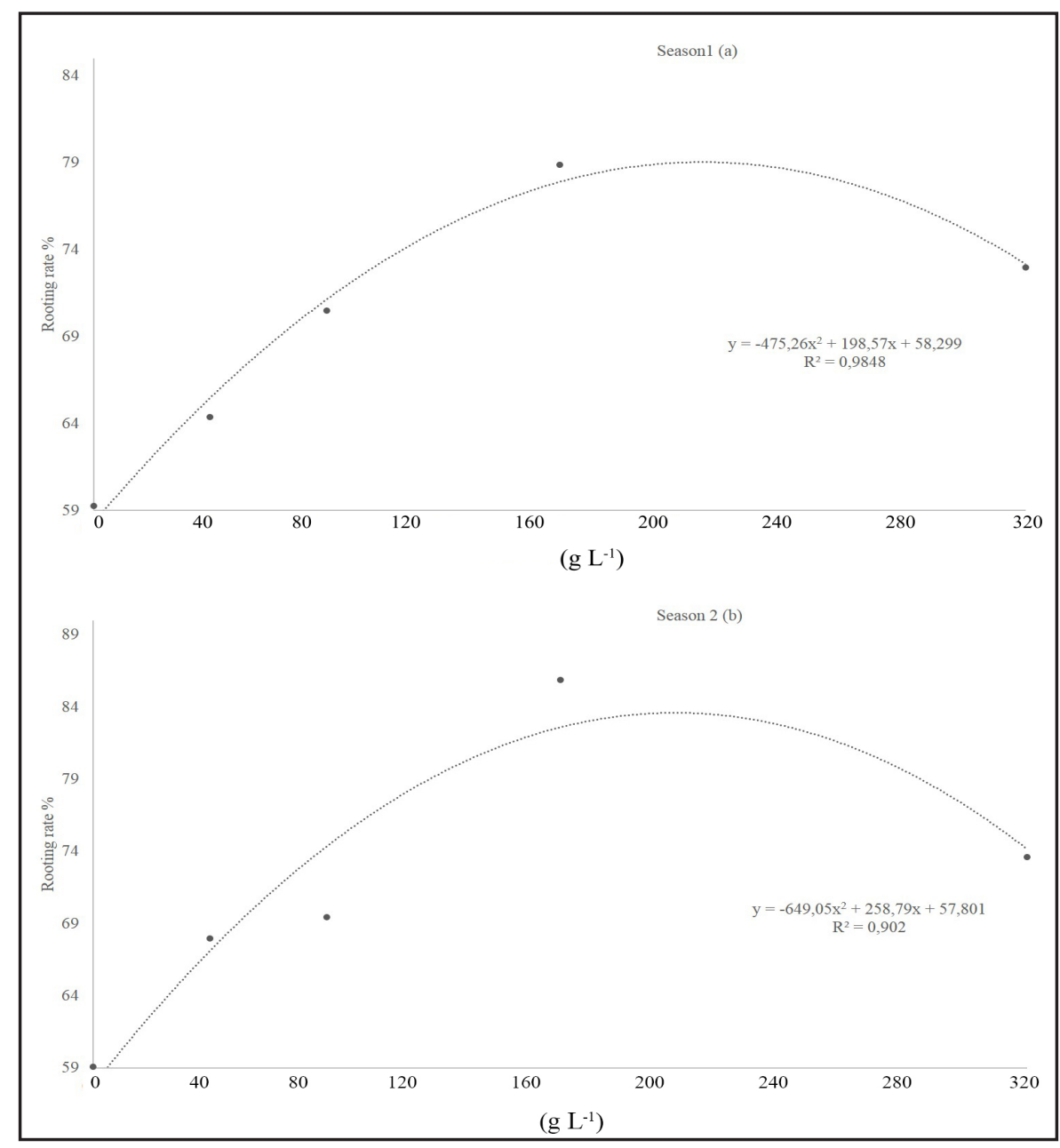

Source: Authors (2017) 
However, the ability of plant tissues to form adventitious roots depends on different endogenous and exogenous factors and their interaction (XAVIER; WENDLING; SILVA, 2009). In this study, the superior rooting results obtained with mini-cuttings treated with fertilizer may be related, among other factors, to the presence of calcium. The composition of the product contains on calcium sulfate and, admittedly, this mineral act on the cell division, the formation of the middle lamella, the process of root formation and the cellular appearance The calcium acts by giving greater lignification to the tissues, which gives them greater resistance, since it is important in maintaining the rigidity of the cellular appearance of plant tissues (CUNHA et al., 2009).

The absence of calcium results in the reduction of root growth, darkening and death of the plant (VITTI; LIMA; CICARONE, 2006), and if this occurs during the formation phase, it can generate a decrease of up to $45 \%$ in the rooting index (BELLAMINE et al., 1998). According to Assis, Fett-Net and Alfenas (2004), low concentrations of calcium in the leaf $\left(<7 \mathrm{~g} \mathrm{~L}^{-1}\right)$ compromise the rooting of Eucalyptus mini-cuttings.

As in the present study that obtained rooting values around 80\%, Martínez Pastur, Arena and Curvetto (2000) also obtained positive responses when evaluating different concentrations of calcium in the culture medium, reaching results with $100 \%$ rooting rate.

In addition to the mineral nutrition function, the benefits of calcium are also related to its activity as activator of enzymes and hormones acting in the rooting process. In this context, there is the relevant interaction of calcium in auxin transport between young tissues (TAIZ; ZEIGER, 2006) and peroxidase activation (HAISSIG, 1986), which mechanisms of action are associated with resistance induction and rooting process (BAYSAL; SOYLU; SOYLU, 2003). However, in this study it was possible to verify, according to the studied variables, a significant interaction between the calcium dosages and the increase of the peroxidase (Figure 4), which certainly provided a higher rooting rate (Figure 3 ).

This result suggests that calcium plays an important role in root formation, either as a mineral or as a secondary messenger of substances such as peroxidase (CUNHA et al., 2009).

In relation to the peroxidase activity in the leaves of clones IPB22 and IPB26 (Figure $4 \mathrm{a}$ and $4 \mathrm{~b}$ ), it was observed that for all doses of calcium sulphate-based fertilizer, there was a significant increase $(\mathrm{p}<0.05)$, which increased proportionally to concentration of the product. The highest increase was observed in the dosage of $320 \mathrm{~g} \mathrm{~L}^{-1}$. For both clones IPB22 and IPB26 it was possible to verify that there was a peak of induction in the first $24 \mathrm{~h}$ after application of fertilizer followed by fall and a new induction peak after $72 \mathrm{~h}$.

Other authors also report this peroxidase enzyme induction behavior, with the increase depending on the dose of treatments and time after them. Boava et al. (2010), for example, reported a higher peak of peroxidase activity $72 \mathrm{~h}$ after inoculation of Puccinia psidii in acibenzolar-Smethyl-induced in eucalyptus.

The increase in the enzymatic activity of minicuttings treated with calcium sulphatebased fertilizer is probably related to the ability of the components of this product to activate plant defense mechanisms, anticipating biochemical reactions that would only be activated, for example, by the attack of a pathogen (BOAVA et al., 2010). 
Figure 4 - Activity of peroxidases in leaf tissues of the IPB 22 (a) and IPB26 (b) clones of Eucalyptus grandis $\mathbf{x}$ Eucalyptus urophylla, submitted to different dosages of calcium

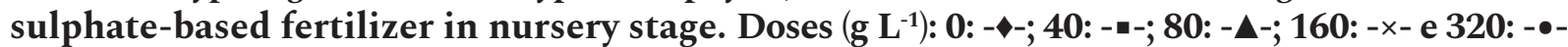

Figura 4 - Atividade de peroxidases em tecidos foliares dos clones IPB 22 (a) e IPB26 (b) de Eucalyptus grandis x Eucalyptus urophylla, submetidos a diferentes dosagens de fertilizante à base

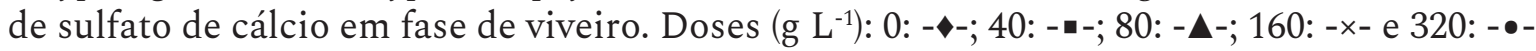

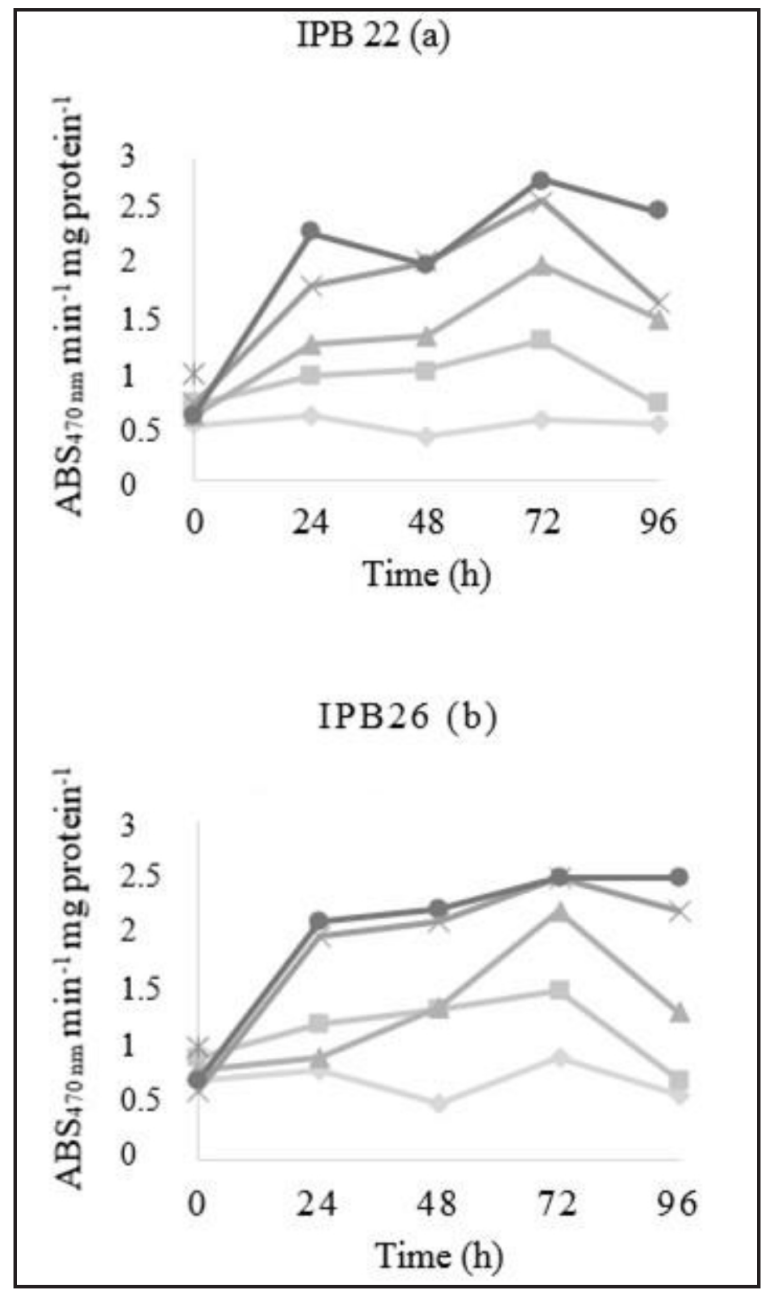

Source: Authors (2017)

The application and the contact of the fertilizer with the leaf may activate the mechanisms of recognition and trigger defense reactions, even in the case of a product contains on calcium sulphate, its absorption by the leaf may favor the activation of enzymes which maintain close relation with the metabolism of calcium in the plant, such as peroxidases (HAISSING, 1986). By providing elevation of peroxidase levels in the plant, several physiological processes can be influenced, as this enzyme participates directly and indirectly in several physiological events, including dormancy, cold tolerance, germination, resistance to parasitism, and biosynthesis (BAYSAL; SOYLU; SOYLU, 2003; TAIZ; ZEIGER, 2006; CUNHA et al., 2009), as observed in the present study. When analyzing Figure 4 and Figure 3 it is possible to verify that the treatments that received doses of fertilizer presented elevation of the levels of peroxidase and, consequently, of the rooting rate, respectively.

This result agrees with other authors, for example, Amarante et al. (2001), who found a positive correlation in the activation of the peroxidase by naphthalene acid in the in vitro rooting 
of asparagus (Asparagus officinalis L.), and Zanol et al. (1997), who verified that the induction of peroxidase by indolbutyric acid results in a better rate of in vitro rooting of apple tree grafts.

However, it can be observed that the doses increment of calcium sulphate-based fertilizer had a positive and significant effect on the morphological characteristics (height, stem diameter and rooting rate) and biochemical characteristics (increase of peroxidase activity) in eucalyptus mini-cuttings. The composition of the product, especially calcium sulphate, interacts with the foliar surface, acting as elicitor, either by induction of resistance or by calcium input, altering the metabolism of mini-cuttings, increasing the peroxidase activity during the rooting period, favoring the formation of adventitious roots. These, in turn, confer better development of minicuttings, represented in this case, by the greater height and stem diameter. However, more research should be done to strengthen these theories.

\section{Conclusion}

The use of calcium sulphate-based fertilizer, in a dose-dependent manner, mainly at 288 $\mathrm{g} \mathrm{L}^{-1}$, increases height, stem diameter and rooting of cuttings of the clones of Eucalyptus grandis $\mathrm{x}$ Eucalyptus urophylla, besides inducing the activity of the peroxidase enzyme.

\section{References}

ALFENAS, A. C. et al. Clonagem e doenças do eucalipto. Viçosa MG: UFV, 2009. 442 p.

AMARANTE, L. et al. Influências do ácido naftaleno acético e escuro e atividade da peroxidase no enraizamento in vitro de aspargo (Asparagusofficinalis L.). Revista Brasileira de Agrociência, Pelotas, v. 7, n. 1, p. 4-9, 2001.

ANSARI, S. A.; PALANISAMY, K.; KUMAR, P. Peroxidase andnitratereductaseactivity in relationtorhizogenesis in Populus deltoidesMarsh. Indian Journal of Experimental Biology, New Delhi, v. 33, n. 11, p. 892-893, 1995.

ASSIS, T. F.; FETT-NET, A. G.; ALFENAS, A. C. Current techniques and prospects for the clonal propagation of hardwood with emphasis on Eucalyptus. In: WALTER, C.; CARSON, M. (Eds), Plant forest biotechnology for the $\mathbf{2 1}^{\text {th }}$ century. New Delhi: Research Sign Post, 2004. p. 303333.

ASSIS, T. F.; MAFIA, R. G. Hibridação e clonagem. In BORÉM, A. (ed.). Biotecnologia florestal. Viçosa, MG: Suprema, 2007. p. 93-121.

BAYSAL, O.; SOYLU, E. M.; SOYLU, S. Induction of defence-related enzymes and resistance by the plant activator acibenzolar-S-methyl in tomato seedlings against bacterial canker caused by Clavibactermichiganensis subsp. michiganensis. Plant Pathology, Turkey, v. 52, n. 6, p. 747-753, 2003.

BELLAMINE, J.et al. Confirmation of the role of auxin and calcium in the phases of adventitious root formation. PlantGrowthRegulation, Netherlands, v. 26, n. 3, p. 191-194, 1998.

BOAVA, L. P. et al. Atividade de quitinases e peroxidases em folhas de eucalipto em diferentes estágios de desenvolvimento após tratamento com acibenzolar-S-metil (ASM) e inoculação com Pucciniapsidii. Tropical PlantPathology, Brasília, v. 35, p. 124-128, 2010.

BORGES, S. R. et al.Enraizamento de miniestacas de clones híbridos de Eucalyptus globulus. Revista Árvore, Viçosa,MG,v. 35, p. 425-434, 2011.

CORREIRA, A. C. G. et al. Redução foliar em miniestacas e microestacas de clones híbridos de Eucalyptus globulus. Revista Árvore, Viçosa, MG, v. 39, p. 295-304, 2015.

CUNHA, A. C. M. C. M. et al. Papel da nutrição mineral na formação de raízes adventícias em 
plantas lenhosas. PesquisaFlorestalBrasileira, Colombo, v. 58, p. 35-47, 2009.

FOOD AND AGRICULTURE ORGANIZATION OF THE UNITED NATION. FAO publications2015. Rome, 2015. Disponível em: http://www.fao.org/3/a-i5056e.pdf.

FERNANDES, S. J. O. et al. Período de enraizamento de miniestacas de eucalipto provenientes de diferentes lâminas de irrigação em minijardim. Ciência Florestal, Santa Maria, v. 28, n. 2, p. 591-600, 2018.

FERREIRA, D. F. Sisvar: a guide for its Bootstrap procedures in multiplecomparisons. Ciência e Agrotecnologia, Lavras, v. 38, n. 2, p. 109-112, 2014.

FREITAS JUNIOR, G.; MARSON, A. A.; SOLERA, D. A. G. Os eucaliptos no Vale do Paraíba Paulista: aspectos geográficos e históricos. RevistaGeonorte, Manaus, v. 1, p. 221-237, 2012.

GASPAR, T. et al. Practical uses of peroxidase activity as a predictive marker of rooting performance of micropropagated shoots. Agronomie, Liège, v. 12, p. 757-7652, 1992.

HAISSING, B. E. Metabolic processes in adventitious rooting of cuttings. In: JACHSON, M. B. (ed.). New root formation in plants and cuttings.Dordrecht: MartinusNijhoff, 1986. p. 141-189.

HARTMANN, H. T. et al. Plant propagation: principles and practices. 8th ed. Boston: PrenticeHall, 2011. 915 p.

INDÚSTRIA BRASILEIRA DE ÁRVORES. Relatório anual2016. São Paulo, 2016. Disponível em: http://iba.org/images/shared/Biblioteca/IBA_Relatorio Anual 2016.pdf.

LUSSO, M. F. G.; PASCHOLATI, S. F. Activity and isoenzymatic pattern of soluble peroxidases in maize tissues after mechanical injury or fungal inoculation. Summa Phytopathologica, Botucatu, v. 25, p. 244-249, 1999.

MARTÍNEZ PASTUR, G.; ARENA, M.; CURVETTO, N. Calcium and boron for in vitro rooting of Nothofagus nervosa. Biocell, Mendonza, v. 24, p. 65-71, 2000.

MARTINS, F. B.; SILVA, J. C.; STRECK, N. A. Estimativa da temperatura base para emissão de folhas e do Filocrono em duas espécies de eucalipto na fase de muda. RevistaÁrvore, Viçosa, MG, v. 31, p. 373-381, 2007.

MATO, M. C.; RÚA, M. L.; FERRO, E. Changes in levels of peroxidases and phenolics during root formation in Vitis cultured in vitro. PhysiologiaPlantarum,Scandinavian, v. 72, p. 84-88. 1998.

SOUZA, C. A. M. et al. Desenvolvimento em campo de espécies florestais em diferentes condições de adubação. Ciência Florestal, Santa Maria, v. 16, p. 243-249, 2006.

SOUZA, C. C. et al. Padrões de miniestacas e sazonalidade na produção de mudas clonais de Eucalyptus grandisHill X Eucalyptus urophylla S. T. Black. Revista Árvore, Viçosa, MG, v. 37, p. 67-77, 2013.

TAIZ, L.; ZEIGER, E. Plantphysiology. 4th ed. Sunderland: Sinauer Associates, 2006. 794 p.

VITTI, G. C.; LIMA, E.; CICARONE, F. Cálcio, magnésio e enxofre. In: FERNANDES, M. S. (ed.). Nutrição mineral de plantas. Viçosa, MG: Sociedade Brasileira de Ciência do Solo, 2006. p. 299-325.

XAVIER, A.; WENDLING, I.; SILVA, R. L. Silvicultura clonal: princípios e técnicas. Viçosa, MG: UFV, 2009. 272 p.

ZANOL, G. C. et al. Escuro e ácido indolbutírico no enraizamento in vitro e atividade da peroxidase de porta-enxerto de macieira, cv. marubakaido (Malusprunifolia). Revista Brasileira de Agrociência, Pelotas, v. 3, p. 23-30, 1997. 